\title{
Dossiê
}

Dramaturgia Musical

\section{A Dramaturgia Musical das Comédias de Luiz Carlos Martins Penna (1838-1874): Companhias, Artistas e Repertórios}

Luiz Costa-Lima Neto

Revista do Laboratório de Dramaturgia - LADI - UnB - V. 2 e 3, Ano 1 


\title{
A Dramaturgia Musical das Comédias de Luiz Carlos Martins Penna (1838-1874): Companhias, Artistas e Repertórios
}

\author{
Luiz Costa-Lima Neto \\ Escola Técnica Estadual de Teatro Martins Penna/ETETMP \\ costalimaneto.luiz@gmail.com
}

\begin{abstract}
Resumo - O presente artigo tem por objetivo esclarecer a dramaturgia musical (MOTA 2008) das comédias de Luiz Carlos Martins Penna, noção que engloba tanto o texto teatral como sua performance. Utilizamos como fontes principais os textos das comédias de Martins Penna, seus folhetins escritos e publicados no Jornal do Commercio entre 1846 e 1847, além de manuscritos autógrafos, anúncios de periódicos oitocentistas e estudos de historiadores. Relacionamos o universo sonoro (mousiké) das comédias de Martins Penna aos polos cômicos da tradição teatral Ocidental (estudo de situações e personagens) e aos polos da performance (coro e solo), contemplando a articulação entre os repertórios autorais de Martins Penna e os repertórios dos artistas brasileiros e portugueses que representaram suas comédias no período 1838-1874.
\end{abstract}

Palavras-chave: Martins Pena; dramaturgia musical; teatro musicado; música teatral; entremez; ópera cômica; Rio de Janeiro.

The Musical Dramaturgy of the Comedies of Luiz Carlos Martins Penna (1838-1874): Companies, Artists and Repertoires

Abstract - This article aims to clarify the musical dramaturgy (MOTA 2008) of comedies of Luiz Carlos Martins Penna, a notion that encompasses both the theatrical text and its performance. As primary sources, we used the texts of the comedies written by Martins Penna, and his serials (folhetins), published in the Jornal do Commercio between 1846 and 1847, as well as nineteenth-century periodicals, studies of historians and handwritten manuscripts. We related the sound universe (mousiké) of the comedies of Martins Penna to the comedic poles of the Western theatrical tradition (a study of situations and characters) and the poles of performance (solo and chorus), contemplating the relationship between the repertoires written by Martins Penna and the repertoires of Brazilians and Portuguese artists who performed his comedies during the period 1838-1874.

Keywords: Martins Pena. Musical Dramaturgy. Musical Theater. Theatrical music. Interlude. Comic Opera. Rio de Janeiro. 


\section{Introdução}

A musicologia brasileira contemplou suficientemente as práticas musicais da corte de D. João VI (1808-1821) e do Primeiro Reinado (1821-1831), período em que a cidade do Rio de Janeiro abrigou uma capela com qualidade musical comparável à de importantes cidades europeias e um teatro "maior do que a ópera de Paris" (CARDOSO 2011:455). O período Regencial (1831-1840) e o início do Segundo Reinado (1840-1889), entretanto, têm sido menos estudados, devido ao fato de a música sacra e a ópera terem então entrado em decadência. A musicologia tendeu a desprezar outras práticas musicais do período, como aquelas relacionadas ao teatro cômico, tema do presente artigo.

Luiz Carlos Martins Penna (Rio de Janeiro, 05/11/1815 - Lisboa, 07/12/1848) é consagrado na historiografia teatral como o fundador da comédia de costumes no Brasil (MAGALDI 1996) - gênero teatral que trata dos hábitos de uma determinada parcela da sociedade abordada pelo dramaturgo de maneira crítica e até satírica (GUINSBURG 2009). As pesquisas sobre as histórias do teatro e da música não têm registrado, contudo, salvo raras exceções (ARÊAS 1987), a contribuição do autor na articulação entre essas duas áreas. Como assinalado pioneiramente por Rabetti (2007:74), a comédia de costumes de Martins Penna consiste numa "espécie inicial de teatro musicado" - décadas antes do surgimento das revistas e operetas, na segunda metade do século XIX.

Conforme assinalamos noutro trabalho (COSTA-LIMA NETO 2014), Martins Penna era músico, além de dramaturgo, por isso suas comédias revelam uma musicalidade evidente. Entre menções nos textos e a utilização em cena de recursos musicais e coreográficos a lista é extensa, incluindo danças, canções com e sem indicação de texto, títulos de obras românticas, nomes de compositores, cantores, instrumentistas e editores, termos técnicos e, por fim, sons de sinos, animais, bofetadas, chicotadas, rojões, flatos etc. O universo sonoro constituído pelo conjunto das comédias de Martins Penna abrange gêneros musicais-coreográficos de origem afro-brasileira colonial (batuque, fado, lundu ${ }^{1}$, miudinho), ibérica (tirana, caxuxa), francesa (contradança), alemã (valsa) e da Bohêmia (polca). Estas danças foram desenvolvidas e misturadas entre si e com outras ainda, originando estilos importantes do teatro musicado nas décadas finais do século XIX e início do XX, como o maxixe - antecessor do samba -, presente nas mágicas e revistas de ano (MENCARELLI 1999; FREIRE 2011:218). Completando o conjunto diversificado, às referências mencionadas somavam-se a ópera italiana, a ópera cômica francesa, a música de concerto europeia romântica e o cantochão.

O presente artigo abrange o período 1838-1874, tendo como início o ano de estreia da primeira comédia de Martins Penna e, como término, o ano em que o ator-cantor-dançarino negro Martinho Correa Vasques, protagonista da comédia O Noviço, representou-a pela última vez, na Bahia. No período compreendido entre 1838 e 1863, as comédias de

1 O lundu afro-brasileiro foi levado para Portugal nas décadas finais do século XVIII, sendo dançado nos teatros da capital lisboeta, junto a modinhas brasileiras e seguidilhas espanholas (CRANMER 2012). Nas décadas iniciais do século XIX, o lundu, misturado a outras danças, apareceu nos salões, teatros e circos de Brasil, Argentina, Peru, Bolívia e Uruguai (VEGA 2007). 
Martins Penna foram encenadas por três companhias dramáticas diferentes, se destacando a companhia do ator e empresário brasileiro João Caetano - da qual Martinho fez parte desde 1843 até 1863 -, tendo como palco principal, o Teatro de São Pedro de Alcântara².

Verificaremos como Martins Penna e os artistas que representaram suas comédias constituíam uma parceria por meio da qual o ator transformava-se em "efetivo colaborador do autor, uma espécie de coautor, que lhe completa o trabalho pela construção cênica do tipo" (MARQUES 1998:39). Esta construção do tipo ou personagem-tipo ${ }^{3}$ era não apenas cênica, mas também musical, possibilitando a criação de uma dramaturgia musical, híbrida de sons, palavras e ações, que influenciava e era influenciada pela tipologia de papeis cômicos da tradição cômica Ocidental e pelo repertório de artistas da época. Como Mota assinala com relação à dramaturgia musical de Ésquilo (2008), o dramaturgo grego era não apenas o autor do texto teatral, mas também o compositor e criador de melodias, além de regente dos coros. A dramaturgia musical consistia da articulação das diferenças entre, de um lado, as partes recitadas pelos atores e, de outro, as partes cantadas pelo coro, que marcavam “o ritmo de representação do espetáculo" (MOTA 2008:77).

Outra noção grega importante neste trabalho será a de mousiké, que se referia tanto à arte dos sons, como à poesia e à dança, simultaneamente. A mousiké abrangia a obra teatral e sua performance, se efetivando "na interação entre o artista-músico-poeta e a audiência" (GENTILI citado por MOTA 2008:23). Como Moreira (2013:21) assinala em seu trabalho sobre a música no teatro de rua contemporâneo, é necessário questionarmos a noção que considera a música como uma arte isolada, "pura", pois, no teatro, o universo sonoro é inseparável da visualidade e dos corpos em movimento. Cumpre repensar a "música" como musicalidade, relacionando-a as potencialidades sonoro-musicais do ator e da cena.

As noções corelacionadas de dramaturgia musical e mousiké possibilitam que percebamos Martins Penna não apenas como comediógrafo pioneiro, mas também como dramaturgo musical, criador de um texto híbrido, no qual as palavras engendram imagens sonoras por meio de uma escuta cênica. Martins Penna era um músico que não apenas imaginava qual ator ou atriz interpretaria melhor este ou aquele papel, como também pensava de maneira semelhante a um compositor que compõe uma música para um intérprete específico - qual artista melhor se adequaria à interpretação dos números musicais de cada comédia. Os repertórios atoriais eram atualizados e reelaborados pelos artistas nos assim chamados "espetáculos em benefício" ${ }^{4}$, onde se desdobravam, muitas vezes, em atores, can-

2 Fundado em 04/10/1813, este teatro recebeu inicialmente o nome de Real Teatro de São João, em homenagem a Dom João VI. Em 1824, após a Independência, passou a chamar-se São Pedro de Alcântara; em 1831, após a abdicação de Dom Pedro I, Constitucional Fluminense e, posteriormente, com a maioridade (antecipada) de Pedro II, novamente São Pedro de Alcântara (SOUZA 2002).

3 Os personagens-tipo eram personagens padronizadas, cujos antecedentes se encontram na Antiguidade greco-latina. Como assinalado por Prado (1976:94), uma companhia brasileira oitocentista que tivesse certo número de artistas (o galã, a ingênua, o pai nobre, a dama galã, a dama central, o cômico, a dama caricata, o tirano ou o cínico e a lacaia) poderia interpretar qualquer personagem, pois todas as variantes reduziam-se a esses modelos ideais.

4 Guinsburg (2009:60-61) assinala que o chamado "espetáculo em benefício" ou simplesmente "be- 
tores e dançarinos, alguns chegando a tocar instrumentos musicais em cena.

Qual a procedência e as características das menções sonoras incluídas nas comédias de costumes de Martins Penna? Como se equivaliam ou se opunham dentro do sistema de relações entre comédia e música? Como as performances musicais ocorriam? Quem cantava, tocava e compunha? Como as músicas e sonoridades aludidas nas comédias estavam relacionadas ao contexto de vida do autor e da sociedade escravocrata do Rio de Janeiro oitocentista?

Para responder a estas questões, utilizaremos como fontes principais neste artigo as comédias de Martins Penna (2007), os folhetins ${ }^{5}$ escritos pelo autor para o Jornal do Commercio, publicados entre 1846 e 1847 (MARTINS PENNA 1965), além de anúncios de periódicos oitocentistas, estudos de historiadores e manuscritos autógrafos. Na primeira parte do trabalho, apresentaremos uma breve biografia contextualizada de Martins Penna e, na segunda parte, contemplaremos a mousiké de suas comédias apresentadas no período $1838-1874$.

\section{Breve biografia e contextualização}

Luiz Carlos Martins Penna nasceu na cidade do Rio de Janeiro, em 05 de novembro de 1815, filho de João Martins Penna, natural do estado de Minas Gerais, e de Francisca de Paula Julieta Penna, nativa do Rio de Janeiro. Tendo ficado órfão de pai com 1 ano de idade e de mãe aos dez anos, foi confiado ao avô, o tenente José Antônio da Costa Guimarães (português) e, depois, a um tio materno, ambos comerciantes, que o destinaram a esta atividade profissional (VEIGA 1877).

O garoto cresceu numa época conturbada politicamente. Aos 7 anos, assistiu o Brasil se tornar independente e, aos dezesseis, testemunhou a crise que levou à renúncia do imperador D. Pedro I e seu retorno a Portugal. Era o início do período das Regências (1831-1840), quando pela primeira vez o país passou a se autogovernar e a sensação de liberdade se viu acompanhada da eclosão de revoltas populares, separatistas e federalistas que ameaçaram seriamente a unidade nacional (CARVALHO 2012).

Em 1835, com a idade de 20 anos, Martins Penna concluiu o curso de comércio, mas por não sentir a vocação para este ramo profissional passou a frequentar a Academia Imperial de Belas Artes. Lá, estudou arquitetura, pintura, estatuária e cenografia, sem, entretanto, concluir o curso. Simultaneamente, entregou-se ao estudo da literatura dra-

nefício" surgiu provavelmente na França, em 1735, quando os artistas da Comédie Française entregaram a renda de um espetáculo a uma atriz que perdera seus bens num incêndio. Bastos assinala que os benefícios eram uma maneira de os artistas "equilibrarem as suas finanças, pela insignificância de alguns ordenados e pelos meses em que não têm contrato" (BASTOS, 1994 [1908]: 24).

5 Os folhetins surgiram no início do século XIX, na França, ocupando o rodapé de uma ou mais páginas dos jornais. Consistiam num tipo de crítica musical mais voltada para o entretenimento do que para a análise musical rigorosa, antes do surgimento dos periódicos especializados em música (Grove Dictionary of Music). Os folhetins franceses que publicavam romances melodramáticos em capítulos seriados chegaram ao Brasil em 1838, com O capitão Paulo, de Alexandre Dumas, seguindo a fórmula "continua no próximo número" (MEYER 1996:281-282). 
mática e das línguas italiana e inglesa, aperfeiçoando-se no francês, que vinha praticando desde os 14 anos, de maneira autodidata. Também nesta época, Martins Penna estudou música e canto, desenvolvendo sua voz de tenor e aprendendo as regras do contraponto (VEIGA 1877).

Em 1837, o jovem terminou de escrever sua primeira comédia, estreada em 1838, mas publicada somente em 1842, pois o autor temia que a publicação de um gênero teatral de baixo status social lhe prejudicasse a obtenção de emprego público. Em 1838, com a ajuda do cunhado, um político conservador ${ }^{6}$, Martins Penna passou a ocupar o cargo de amanuense (escriturário) na Ponte do Consulado no Cais dos Mineiros, onde, até abril de 1843, se entediava anotando as quantidades das cargas embarcadas e desembarcadas dos navios. A partir desta data, Martins Penna foi transferido para o Ministério dos Estrangeiros, preparando-se para servir no exterior, como diplomata (MAGALHÃES JÚNIOR 1972:17-18).

Nos anos de 1838 e 1839, Martins Penna fez publicar quatro crônicas nos periódicos Gabinete de Leitura e Correio das Modas (SOBRINHO 1960), mas foi com sua obra teatral que se consagrou. Entre os anos de 1833 a 1847, o autor compôs um total de 27 peças, sendo 22 comédias (18 em um ato e 4 em três atos) - das quais nos chegaram 20 textos (alguns incompletos) (RONDINELLI 2012:2). Além das comédias, Martins Penna escreveu cinco dramas históricos, dos quais apenas um foi encenado em vida do autor (ARÊAS 1987). A partir de 1842 até o ano de 1855, suas comédias foram publicadas pela tipografia do poeta negro Francisco de Paula Brito (1809-1861), disputando o topo da preferência dos leitores, junto aos libretos traduzidos de ópera italiana. As comédias de Martins Penna, vendidas a um preço relativamente barato (600 réis) ${ }^{7}$, ultrapassaram os álbuns de romances e coletâneas de poesias, fazendo dele o "best-seller da literatura dramática brasileira naquele momento" (GODÓI 2010: 233).

A atuação profissional de Martins Penna está relacionada à sua trajetória como homem público pioneiro, envolvido com a educação artística no Rio de Janeiro e a criação de instituições públicas de ensino de teatro e música. Em 30 de maio de 1843, ele participou da fundação do Conservatório Dramático Brasileiro, associação que tomava como modelo o Conservatoire, de Paris, e o Real Conservatório Dramático, de Lisboa. Originalmente, se visava fundar uma escola de declamação e arte dramática, criar um jornal para divulgar os trabalhos da associação e estabelecer a crítica literária. Em novembro de 1843, contudo, o governo imperial delegou ao Conservatório Dramático a atribuição de examinar previamente as peças a serem encenadas no principal teatro da cidade do Rio de Janeiro, o Teatro de São Pedro de Alcântara e, dois anos depois, em todos os tea-

6 O senador Joaquim Francisco Vianna, casado com a irmã de Martins Penna, a Sra. Carolina Penna Vianna (VEIGA 1873:380).

7 Para fins de comparação, com base nos anúncios publicados no Diário do Rio de Janeiro, entre 1821 e 1850, informamos que um exemplar deste jornal custava 60 réis, onde a venda de partituras de modinhas com acompanhamento de piano ou violão eram anunciadas por cerca de 200 réis. Um realejo grande custava 80.000 réis, enquanto que um piano de 5 oitavas, 120.000 . Um escravo negro era vendido ilegalmente por 600.000 a 800.000 réis. 
tros cariocas. A partir de então, "a associação começou a atuar como instrumento oficial auxiliar em prol da efetivação de uma política de controle dos divertimentos públicos considerados convenientes aos habitantes da cidade" (SOUZA 2002:145). O Conservatório Dramático foi, dessa maneira, gradativamente abandonando o projeto inicial de desenvolvimento da arte dramática e passou a órgão oficial de censura teatral, atuando conjuntamente com a polícia.

Em fins de 1845, causando escândalo entre seus membros, o Conservatório Dramático censurou a comédia Os ciúmes de um pedestre ou $O$ terrível capitão-do-mato, de Martins Penna, o qual ocupava então o importante cargo de $2^{\circ}$. Secretário da associação. Meses antes, neste mesmo ano, outra comédia de Martins Penna, Os dois ou o inglês maquinista, também fora censurada, pela Câmara dos Deputados. Para compreendermos os motivos das censuras às duas comédias é vital abordarmos o contexto histórico da época. No período compreendido entre 1831 e 1850, abrangendo aquele em que Martins Penna escreveu sua obra, foram desembarcados no Rio de Janeiro mais de 750.000 escravos africanos, infringindo tratados internacionais e a legislação nacional, que haviam tornado ilegal o tráfico negreiro (CHALHOUB 2012). Estava no auge, nesta época, a contenda entre Brasil e Inglaterra, diante da qual certas camadas da sociedade defendiam o "direito soberano" de o Brasil continuar a praticar o comércio negreiro, enquanto os navios ingleses policiavam as águas continentais brasileiras para coibir o tráfico. Martins Penna foi censurado ao criticar o tráfico negreiro ilegal e suas engrenagens, como exemplifica o diálogo a seguir, extraído da comédia Os dois ou o inglês maquinista, entre os personagens Felício e Negreiro (um traficante de escravos):

FELÍCIO - Sr. Negreiro, a quem pertence o brigue Veloz Espadarte, aprisionado ontem junto quase da Fortaleza Santa Cruz pelo cruzeiro inglês, por ter a bordo trezentos africanos?

NEGREIRO - A um pobre diabo que está quase maluco... Mas é bem feito, para não ser tolo. Quem é que neste tempo manda entrar pela barra um navio com semelhante carregação? Só um pedaço de asno. Há por aí além de uma costa tão longa e algumas autoridades tão condescendentes!...

(MARTINS PENNA, 2007 [1842]:146, vol. I - nossos grifos).

$\mathrm{Na}$ cena referida acima era intencional a menção ao brigue ou navio negreiro Veloz Espadarte, pois havia de fato, não apenas um, mas dois navios "tumbeiros" (assim chamados por serem como "tumbas" ou "túmulos flutuantes") denominados Espadarte e Veloz. O primeiro destes tinha como proprietário ninguém menos que o português José Bernardino de Sá ${ }^{8}$, presidente da diretoria do Teatro de São Pedro de Alcântara, notório

8 José Bernardino de Sá (1802-1855) foi empregado de uma loja antes de iniciar sua carreira de traficante negreiro em 1830, um ano antes de o tráfico ter se tornado totalmente ilegal. Naquele ano, Bernardino passou a embarcar escravos para o Brasil em seu próprio navio, curiosamente chamado Amizade Feliz. Após receber uma herança que investiu no tráfico, ele instalou postos escravistas na costa africana, onde fazia o escambo de tecidos ingleses por escravos, enquanto utilizava a bandeira portuguesa para se proteger dos navios de captura ingleses. $\mathrm{O}$ jovem comerciante logo 
traficante de escravos internacionalmente conhecido e "patrão" de Martins Penna:

Há dados a indicar ter ele [José Bernardino de Sá] armado cinquenta viagens negreiras entre 1829 e 1851. Em dezenove delas, feitas entre 1829 e 1840, desembarcou 9.164 escravos, deixando mortos na travessia 793, uma chacina. Numa dessas viagens, em 1839, a bordo do bergantim Espadarte, vieram espremidos 677 escravos, o que resultava em menos de cinquenta centímetros quadrados, talvez menos de quarenta para cada um deles, 67 dos quais não conseguiram sobreviver (REIS 2010: 200-201).

A tensão entre Martins Penna e a direção do Teatro de São Pedro chegou ao auge com a censura do Conservatório Dramático à comédia Os ciúmes de um pedestre ou O terrível capitão-do-mato. Esta comédia é uma paródia da tragédia Otelo, o mouro de Veneza, de William Shakespeare (traduzida por Jean-François Ducis), cujo papel principal era interpretado pelo ator e empresário brasileiro João Caetano (PRADO 1972). Este recorreu ao tom grave de sua voz "para trazer à ideia do espectador o rugido de um furioso leão africano" (SANTOS 1862:26), animal-símbolo do general Otelo, enciumado e enfurecido com a suposta traição de sua amada. Na comédia de Martins Penna, por sua vez, o personagem parodicamente correspondente ao general de Otelo é André Camarão, um odioso policial pedestre (encarregado pela perseguição e captura de escravos fugidos), que mantém aprisionadas em casa suas mulher e filha, com medo de ser traído e abandonado por ambas. A paródia cômica do Otelo, aumentada pela sátira de Martins Penna contra a instituição policial na Corte imperial, motivou a censura da comédia pelo Conservatório Dramático Brasileiro, e o consequente desligamento do autor dos quadros da instituição.

Após as duas censuras, a diretoria do Teatro de São Pedro passou a boicotar Martins Penna, parando de adquirir suas comédias e traduções. É neste momento que o autor passou a escrever folhetins líricos sobre os espetáculos apresentados nos principais teatros cariocas, publicados no Jornal do Commercio, entre 8 de setembro de 1846 e 6 de outubro de 1847. Os folhetins de Martins Penna, num total de 52, versavam principalmente sobre as apresentações de ópera séria italiana e ópera cômica francesa realizadas, respectivamente, nos dois maiores teatros da Corte: o Teatro de São Pedro de Alcântara e o Teatro de São Francisco, cada qual com duas companhias; uma dramática e outra lírica. Como assinalamos noutro trabalho (COSTA-LIMA NETO 2014), os folhetins evidenciam que Martins Penna era músico, pois dominava a partitura e detinha conhecimentos sobre registros vocais e instrumentais, andamentos, tonalidades, ornamentação, harmonia e orquestração, além de cantar, compor árias e conhecer as escolas de canto, os enredos das óperas, seus personagens, cenários etc.

Os folhetins possibilitam, ainda, verificarmos as hierarquias artísticas do período. Assim perceberemos as motivações socioeconômicas e estéticas que levaram o folhetinista, dramaturgo e músico Martins Penna a se engajar em campanha pela criação do Con-

ficou rico, tendo recebido altas honras e condecorações, como a de Barão de Vila Nova do Minho (CONRAD 1985:120-122; 167). 
servatório de Música, três anos após ter fundado o Conservatório Dramático. O autor deixou assinalado nos folhetins que, ao contrário dos bem remunerados solistas estrangeiros de ópera italiana - financiados pela diretoria de grandes comerciantes e traficantes negreiros do Teatro de São Pedro -, os coristas brasileiros percebiam os piores vencimentos entre todos os artistas do teatro, sendo "obrigados a trabalhar, como os condenados a galés, por um salário que apenas pode suprir as suas mais urgentes necessidades" (Folhetins [14/10/1846]:48). Havia dificuldades em se constituir um bom coro, especialmente quanto às coristas, pois as mulheres que sabiam ler música e que demonstravam "uma educação mais cultivada" resistiam a aceitar "uma posição tão mal conceituada e de insignificantes vantagens" (Folhetins [14/10/1846]:46). Segundo Martins Penna, a criação do Conservatório de Música desempenharia uma função social importante, ao atender os alunos oriundos das camadas economicamente menos favorecidas da população, os quais não conseguiam "seguir uma arte liberal por lhes falecerem os meios necessários" (Folhetins [14/10/1846]:48). Entre estes alunos, é importante destacar, estariam homens livres pobres e descendentes de escravos, ${ }^{9}$ os quais se formariam no Conservatório de Música como coristas, solistas e instrumentistas de um novo gênero de música e teatro, que Martins Penna planejou, mas não teve tempo de criar:

Entre nós existem compositores que só esperam o momento e animação para nos oferecerem seus trabalhos: o público, que corre ansioso ao teatro da ópera cômica francesa ${ }^{10}$, para ver um drama que muitas vezes não entende e ouvir música bem diversa da do estilo e gosto nacional, não deixará de sustentar com empenho e aplaudir a ópera cômica brasileira, que para ele será escrita. Longe não está talvez a realização desta ideia (Folhetins, 1965 [8 de junho de 1847], p. 257). ${ }^{11}$

9 Segundo relato de viajantes que estiveram no Rio de Janeiro, em 1844, o coro do Teatro de São Pedro era integrado principalmente por "mulatos", assim como parte dos músicos da orquestra (Galante de Sousa apud ARÊAS 1987:22).

10 As origens da opéra comique remontam aos teatros ao ar livre, que funcionavam na França por volta de 1715. O termo designa espetáculos franceses dos séculos XVIII, XIX e XX com música instrumental e vocal, diálogos falados e, eventualmente, recitativos. O repertório, de apelo popular, se opunha à ópera séria. A partir dos anos 1750-1760 se consolida o termo comédie mêlée d'ariettes ("comédia mesclada de arietas"). Com a Revolução Francesa, o significado de opéra comique permaneceu ligado ao de vaudeville e, nas primeiras décadas do século XIX, o termo adquiriu o sentido atual: ópera francesa com diálogos falados (GUINSBURG 2009:247). Em Portugal, vaudevilles isolados de Eugène Scribe foram apresentados desde 1822, mas a primeira opéra comique completa de Daniel Auber (1782-1871) e Eugène Scribe (1791-1861) só foi encenada em 1841, sendo recebida com um misto de estranheza e entusiasmo pelas plateias lisboetas, num contexto onde a vida operática se reduzia ao melodrama italiano (CYMBRON 2012:172; 195-196). No Brasil, vaudevilles foram apresentados a partir de 16 de setembro de 1840, por uma companhia francesa ambulante, na Sala de São Januário (SOUZA 2007).

11 O protesto de Martins Penna em prol da criação do Conservatório surtiu efeito e, em janeiro de 1847, foi extraída a primeira loteria autorizada pelo governo para a instituição, finalmente inaugurada em 13/08/1848. É a atual Escola de Música da Universidade Federal do Rio de Janeiro/UFRJ (AUGUSTO 2008). 
Martins Penna vendia suas comédias e traduções para a diretoria do Teatro de São Pedro por um preço baixo (Folhetins [29/06/1847]:271), estando próximo à base da hierarquia sócio-profissional deste teatro, junto aos coristas e músicos da orquestra. Por isso, quando estes artistas entraram em greve, em 1847, pelo pagamento de salários atrasados, entre outras reivindicações, foram publicamente apoiados pelo colega folhetinista, motivando a fúria do jornal Mercantil, porta voz da diretoria do Teatro de S. Pedro. A carta publicada neste jornal, em 08/07/1847, exemplifica como a diretoria do São Pedro tentava desqualificar Martins Penna, chamando-o de "empregado da casa" e "exímio vendedor de comédias [que] não prestavam". ${ }^{12}$ Contradiz este discurso o fato de, em 1845 e 1846, terem estreado naquele teatro quatorze comédias do autor, quantidade expressiva que possibilita verificarmos seu prestígio junto ao público.

Em meio à crise teatral causada pela censura da Câmara dos Deputados, do Conservatório Dramático e da diretoria do Teatro de São Pedro de Alcântara, uma semana após escrever seu último folhetim Martins Penna embarcou para Londres, trabalhando no consulado inglês entre fevereiro e outubro de 1848. Em novembro deste mesmo ano, solicitou e obteve licença médica, pois o clima frio e úmido londrino precipitara a moléstia pulmonar que vinha se agravando desde 1843 (MAGALHÃES JÚNIOR 1972). Com a saúde seriamente comprometida, Martins Penna chegou a Lisboa, de onde esperava zarpar de volta para o Brasil em busca de um clima mais propício, mas não resistiu à tuberculose e faleceu em 7 de dezembro de 1848, aos 33 anos de idade.

\section{A mousiké das comédias de Martins Penna}

No período compreendido entre 1838 e 1863 - respectivamente, o ano de estreia da primeira comédia de Martins Penna e o ano de morte do ator João Caetano - as comédias do autor foram encenadas por três companhias dramáticas diferentes, tendo como destaque a companhia de João Caetano. Após a morte do ator, até o ano de 1874, uma das estrelas de sua companhia, o ator-cantor-dançarino negro Martinho Correia Vasques (1822-1890) continuou representando o papel principal da comédia O noviço, no Rio de Janeiro e em províncias como na Bahia. Contemplamos, a seguir, a mousiké de cinco comédias de Martins Penna apresentadas no período 1838-1874, visando responder às questões colocadas na introdução.

\section{8-1840 - Companhia dramática brasileira de João Caetano}

As primeiras comédias de Martins Penna, O juiz de paz da roça e A família e a festa da roça, foram estreadas no Teatro de São Pedro ${ }^{13}$, respectivamente, em 1838 e 1840, em benefício da atriz e dançarina brasileira Estela Sezefreda (1810-1874), esposa de João

12 Como assinalado por Arêas (1987), a controvérsia com o Mercantil acabou sendo útil ao revelar dados musicais de Martins Penna, o qual cantava em teatros particulares junto ao "público salão" e compunha árias.

13 Então denominado Teatro Constitucional Fluminense. 
Caetano. De acordo com o manuscrito do autor, datado de $1837,{ }^{14}$ a farsa $O$ juiz de paz da roça - mista de história de amor e sátira política - seria encerrada com um número de dança, uma tirana, acompanhada pela viola ${ }^{15}$ :

JUIZ - Senhor Escrivão, faça o favor de ir buscar a viola, enquanto eu arranjo a roda [...]. A noiva dança comigo e o noivo com sua sogra. Os outros senhores queiram se abancar. Dançam a Tirana. Os que estão assistindo vão tocar palmas, [os] outros, cacos e pratos. (MARTINS PENNA 1837).

Em 1842, quando da primeira edição da comédia, publicada pela Tipografia Imparcial de Paula Brito, a tirana foi acrescida de uma canção com letra indicada no texto: um fado, cujas estrofes são cantadas alternadamente pelo "tocador" e respondidas pela roda de dançarinos e cantores, acompanhada pela viola, além das palmas, pratos e $\operatorname{cacos}^{16}$ percutidos pelo "coro":

TOCADOR (cantando)

Ganinha minha senhora,

Da maior veneração;

Passarinho foi-se embora,

Me deixou penas na mão.

\section{TODOS}

Se me dás que comê,

Se me dás de bebê,

Se me pagas as casas,

Vou morar com você. (Dança).

(MARTINS PENNA 2007 [1842]:47-48, vol. I).

A tirana e o fado da comédia de Martins Penna - dos quais não foram escritos ou não restaram registros em partitura - eram adequados ao repertório da atriz-dançarina Estela Sezefreda. Segundo os anúncios de periódicos, desde o ano de 1822 até 1838, Estela vinha dançando no Real Teatro de São João os principais gêneros de dança da época. Dentre estes, o "Lundu de Monroi", a cachucha e o fandango espanhóis, além do solo inglês - que ela dançava "vestida de homem", de "militar" ou "à antiga Brasileira"17.

A tirana era uma dança-canção de origem andaluza, com compasso ternário ou binário composto e ritmo sincopado, que, entre 1780 e 1790, experimentou grande voga

14 Depositado no Setor de Manuscritos da Biblioteca Nacional do Rio de Janeiro, localizador I-6, 27, $1 \mathrm{n}^{\circ} 1-3,1837$.

15 "Viola" designa o instrumento de dez cordas (cinco cordas duplas), de tamanho pouco menor ao de um violão.

16 "Pratos e cacos" eram, originalmente, objetos de sucata usados como percussão pelos escravos nas rodas de dança, canto e batuque. Cf. Debret (1816-1831), citado por Lago (2009:166).

17 Para mais informações sobre o solo inglês ver Andrade (1989:484). 
na Espanha, aparecendo no final das tonadillas cênicas ${ }^{18}$. Segundo Budasz (2008:14), a tirana foi dançada pela primeira vez no Brasil, em Cuiabá, em 1790, por um ator negro, no papel de velho enamorado, no final de um entreme ${ }^{19}$ encenado num tablado improvisado ao ar livre. Guilherme de Melo, autor da primeira obra sobre a história da música no Brasil, assinala que a tirana foi um dos "três tipos populares da arte musical brasileira", junto ao lundu e à modinha (MELO 1947 [1908]:29). Devido ao contato com o lundu, a tirana adquiriu a umbigada - movimento coreográfico que ocorre quando o ventre da mulher bate à altura do ventre do homem (ALVARENGA 1982). É importante notar que a umbigada é mencionada ironicamente numa das cenas centrais da comédia $O$ juiz de paz da roça. Durante as audiências realizadas na casa do juiz de paz bronco e corrupto, o escravo negro Gregório é acusado de ter dado uma "embigada" em sua patroa portuguesa:

JUIZ - É verdade, Sr. Gregório, que o senhor deu uma embigada na senhora?

GREGÓRIO - É mentira, Sr. Juiz de paz, eu não dou embigadas em bruxas. JOSEFA JOAQUINA - Bruxa é a marafona de tua mulher, malcriado! Já não se lembra que me deu uma embigada, e que me deixou uma marca roxa na barriga? Se o senhor quer ver, posso mostrar.

JUIZ - Nada, nada, não é preciso; eu o creio.

JOSEFA JOAQUINA - Sr. Juiz, não é a primeira embigada que este homem me dá; eu é que não tenho querido contar a meu marido.

(MARTINS PENNA 2007 [1833-1837]:23-24, vol. I).

Comparável ao que Chiaradia (2012:149) assinala com relação ao teatro de revista carioca de inícios do século XX acreditamos que as menções musicais e coreográficas presentes nos textos de suas comédias de Martins Penna sugeriam aos atores um campo rico de improvisação musical, coreográfica e gestual, mesmo quando não haviam didascálias para a realização das cenas.

O fado, por sua vez, é referido nos relatos de viajantes desde as décadas iniciais do século XIX como dança de origem negra:

A dança favorita dos pretos chama-se Fado. Consiste num movimento que faz ondular suavemente e tremer o corpo, e que exprime os sentimentos mais voluptuosos da pessoa de uma maneira tão natural como indecente. As posições desta dança são tão fascinantes que não é raro vê-la ser dançada por bailarinos

18 A tonadilla cênica tem, principalmente, tipos de classe baixa, como camponeses, ciganos e barbeiros, os quais rapidamente ganharam aceitação popular na Espanha e na América Latina. Seu repertório consistia de seguidilhas, tiranas, fandangos, folias, jotas e outras danças espanholas (LOLO 2002).

19 O entremez era um gênero teatral em um ato, de caráter jocoso, surgido no século XVII, na península ibérica, sendo apresentado entre os atos da peça principal (comédia, tragédia ou drama) ou no final do espetáculo. Sua função principal consistia em atenuar a tensão dos dramas mais longos e era geralmente terminado por um número musical-coreográfico (ARÊAS, 2007:xi). Constituído hibridamente por matrizes musicais luso-ibéricas e afro-brasileiras o entremez chegou ao Brasil em fins do século XVIII (BUDASZ 2008:5-22). 
europeus, com sonoro aplauso, no Teatro de São Pedro de Alcântara (SCHLICHTORST (1825-1826), apud NERY 2004:19-20).

A primeira referência ao fado por nós encontrada num jornal do Rio de Janeiro data de 1833. No final de um entremez publicado no periódico As Obras de Santa Engracia há uma descrição um tanto quanto onomatopaica do fado, feita por um personagem cômico:

ESTOUVADO - Muito gosto de dançar... assim meu bem... venha saindo meu Ripanso, quebra meu negro, derrete candimba... miudinho... moderado... furrundú... furrundú... furrundú... [...] por baixo ladrãozinho... esses pezinhos... a barriguinha... toma coco ioiô... assim meu bem... meu Ripansinho... machuca meu negro [...] derrete-me todo já, toma embigada (As Obras de Santa Engracia, 04/12/1833).

O fado, que era dançado por até oito pessoas (NERY 2004), foi misturado à tirana na comédia $O$ juiz de paz da roça de Martins Penna, como evidencia um anúncio publicado no Diário do Rio de Janeiro, em 07/06/1844. O número final do "fado da tirana" aparece em destaque no anúncio, como importante atrativo teatral-musical-coreográfico para o espetáculo em "benefício de uma liberdade" realizado no Teatro de São Francisco. A receita gerada pelos bilhetes vendidos na tipografia de Paula Brito - editor das comédias de Martins Penna - visava à compra da alforria de um escravo. O exemplo ilustra a inclusão de um gestual musical negro, o qual, apropriado e ressignificado pos artistas e homens de letras da incipiente classe média urbana carioca, servia de estratégia de resistência contra o regime escravocrata.

A comédia A família e a festa da roça, por sua vez, era terminada com um cortejo do Divino Espírito Santo (associado à festa colonial de origem portuguesa), ao fim do qual um "folião" cantava acompanhado por violas, tambores e pandeiros, seguido pelo lundu tocado pela banda de músicos barbeiros ${ }^{20}$ :

À folia! À folia! (os foliões saem para a frente e, fazendo todos um círculo, os metem no meio)

FOLIÃO (cantando)

A pombinha está voando

Pra fazê nossa folia,

Vai voando, vai dizendo:

Viva, viva esta alegria.

(dançam e todos aplaudem com palmas, bravos e vivas)

FOLIÃO (cantando)

20 Os conjuntos instrumentais designados genericamente de "barbeiros" eram integrados por escravos e libertos que tocavam danças europeias (valsas, quadrilhas com contradanças francesas) e íbero-afro-americanas (como o lundu). As músicas eram tocadas em instrumentos de sopro (pistom, trompa, clarineta), cordas (viola, violino) e percussão (tambor e pandeiro) (TABORDA 2011:118). 
Esta gente que aqui está

Vem pra vê nosso leilão,

Viva, viva a patuscada

E a nossa devoção!

(dançam. Os sinos repicam, os barbeiros tocam o lundu e todos dançam e gritam, e abaixa o pano)

(MARTINS PENNA 2007 [1837]:138, vol. I).

Assim como em $O$ juiz de paz da roça, o final musical da comédia A família e a festa da roça também parece ter sofrido a influência do repertório dos artistas da época. A comédia estreou em 01/09/1840, em benefício da atriz-dançarina Estela Sezefreda e, um mês depois, em 06/10/1840, da atriz cômica, cantora e dançarina portuguesa Maria Cândida de Souza. Sabemos pela crítica publicada no Jornal do Commercio, em 5 de setembro de 1840, que Estela Sezefreda desempenhou o papel de Quitéria, conquistando os aplausos da plateia com as hilariantes alusões a São João de Itaboraí - cidade natal de João Caetano. Ao que tudo indica, o papel de Joana da Conceição, mãe de Quitéria, foi representado por Maria Cândida.

Maria Cândida de Souza era uma "farsante exímia", chegada ao Brasil logo após a inauguração do Real Teatro de São João, em outubro de 1813, junto à Companhia Dramática liderada por Mariana Torres (PRADO 1972:16; SOUZA 1968:163). A pesquisa nos periódicos mostra que seu nome aparece desde novembro de 1821 até o ano de 1842 , em comédias, farsas e dramas. Em vários anúncios Maria Cândida aparece cantando e dançando "duetos à brasileira", como "Foi-se embora enfadadinho" e o lundu do "Mestre Alfaiate" 21 , além de modinhas. Seu parceiro mais constante nestes duetos foi o também veterano português Victor Porfírio de Borja, especialista em papéis bufos, "com preferência pelos entremezes em que se cantava e dançava a moda popular portuguesa" (PRADO 1972:11). É interessante notar que, em 1789, Borja era terceira dama do Teatro do Salitre, em Lisboa, numa época em que os escrúpulos da Rainha D. Maria I levaram-na a proibir que as mulheres subissem à cena nos teatros públicos da capital (BRITO 1989:107). Os lundus, contudo, durante a vigência da proibição, continuaram a ser apresentados nos palcos,

dançados por pares em que o papel feminino era desempenhado por um bailarino maquiado e vestido de mulher (mas ao que parece nem por isso menos eficaz dos requebros do jogo de ancas, gerando alguns equívocos que o anedotário da época não deixa de registrar (NERY, 2004: 27). ${ }^{22}$

21 O dueto e o lundu referidos foram criados pelo compositor português Bernardo José Sousa de Queiroz. Este atuou junto ao Real Teatro de São João como compositor de música de cena desde o ano de sua inauguração, 1813, até o início da década de 1830, quando o governo regencial (18311840) decidiu dispensá-lo e à maioria dos músicos do teatro. Cf. Budasz (2008:112); Cardoso (2011).

22 Em 10/05/1846, Victor Porfírio de Borja atuou na comédia de Martins Penna As desgraças de uma criança, tendo como ensaiador João Caetano. Cf. Revista Dyonisos (1966:85). 
Maria Cândida chegou ao Brasil com o nome de Maria Cândida de Souza, mas em 1822, com a Independência do Brasil, mudou seu sobrenome artístico para Maria Cândida "da Conceição" e, em 1831, após a abdicação de D. Pedro I, para Maria Cândida "Brasileira". ${ }^{23}$ É provável que o nome da personagem "Joana da Conceição" (mãe de Quitéria, em A família e a festa da roça), seja uma referência ao sobrenome artístico de Maria Cândida (da Conceição). Este e outros exemplos análogos revelam como os textos das comédias de Martins Penna eram adaptados e, em alguma medida, criados, segundo o elenco e os recursos disponíveis em cada montagem.

\section{4-1848 - Companhia dramática portuguesa}

Após brigar com a diretoria do Teatro de São Pedro, em 1840, João Caetano e companhia passaram por diversos teatros, até ocuparem, em 1846, o Teatro de São Francisco ${ }^{24}$. Como João Caetano preferia os melodramas e vaudevilles franceses às comédias brasileiras, Martins Penna acabou tendo a grande maioria de suas peças representadas, entre os anos de 1844 a 1848, pela companhia dramática portuguesa do Teatro de S. Pedro, chegada ao Brasil em 1829 (PRADO 1972).

Ao escrever as comédias a serem representadas pela companhia portuguesa, Martins Penna mudou os números musicais de lugar na estrutura da peça, deslocando-os do final para o início ou o meio da narrativa. Além dessa diferença, os números, que antes estavam associados a situações, como bailes de casamento e cortejos na "roça", sendo dançados e/ou cantados predominantemente por um "coro", passaram a estar relacionados aos personagens-tipos, sendo cantados em solos, duos e trios25. Os números foram liderados musicalmente por artistas como o ator, barítono e dançarino português José Cândido da Silva, elogiado por Martins Penna no folhetim abaixo:

Havia na companhia dramática do Teatro de São Pedro um ator, [o] Sr. José Cândido da Silva, que mostrava grandes disposições para cantar bufo; muitos aplausos colheu em cena cantando duetos, árias e tonadilhas ${ }^{26}$, e mais uma

23 As informações sobre Maria Cândida de Souza foram colhidas em exemplares do Diário do Rio de Janeiro, publicados entre os anos de 1821 a 1842.

24 O Teatro de São Francisco foi construído em 1832, para servir como uma pequena sala de espetáculos destinada à "encenação de atores amadores franceses, que trabalhavam como caixeiros, modistas e contramestres na Rua do Ouvidor" (SOUZA 2002: 41).

25 Utilizamos aqui o trabalho fundamental do historiador de teatro Sábato Magaldi (2004 [1996]) sobre Martins Penna e a criação da comédia brasileira, onde são apresentados os dois polos cômicos da tradição teatral: o do estudo da situação e o de caracteres, tendo como representantes ilustres o grego Aristófanes (Atenas 444 - 380 a. C.) e o francês Molière (1622-1673).

26 As tonadillas eram cantadas entre os atos de uma peça ou (mais raramente) de uma ópera durante o teatro espanhol dos séculos XVIII e XIX. Originalmente era uma canção estrófica que usualmente precedia a dança. A tonadilla teatral é muitas vezes referida como tonadilla cênica. Tinha principalmente personagens de classe baixa, como camponeses, ciganos e barbeiros, os quais rapidamente ganharam aceitação popular, primeiro em Madrid, depois em toda a Espanha e na América Latina. Seu repertório consistia de seguidilhas, tiranas, fandango, folia, jota e outras danças 
vez lastimamos que não procurasse ele dar desenvolvimento, por meio de regulares estudos, ao seu talento natural (MARTINS PENNA, Folhetins, 1965 [25/08/1847]: 340).

A partir da pesquisa nos periódicos oitocentistas reconstituímos parcialmente a trajetória e o perfil atorial de José Cândido da Silva. O artista atuou nos teatros da Corte desde 1833 até 1854, representando tanto dramas e tragédias, como comédias e farsas. Seu repertório consistia de modinhas e lundus ("Iaiazinha meus gostinhos"), duetos e tercetos cômicos ("Foi-se embora enfadadinho", "Os pombinhos", "O terceto dos pretos", "O taberneiro"), árias e duetos de ópera, além de paródias cômicas, como o dueto de $O$ barbeiro de Sevilha, "O posto abandonado", "O meirinho e a pobre", a "engraçada ária Os sorvetes" e, por fim, polcas e tonadillas. ${ }^{27}$

Em benefício de José Cândido estrearam as comédias Os irmãos das almas e Quem casa quer casa, respectivamente em 1844 e 1845. Considerando o perfil atorial de José Cândido é possível supor que o artista tenha atuado em outras comédias que exigiam habilidades musicais especiais por parte dos atores, como é o caso da comédia $O$ diletante. Nesta comédia, José Cândido parece ter desempenhado o papel do diletante José Antônio, enquanto que o ator Germano de Oliveira, em cujo benefício a comédia foi estreada, interpretou o papel do "paulista" Marcelo ${ }^{28}$.

José Antônio é um diletante ${ }^{29}$ apaixonado pela ópera italiana, especialmente a Norma, de Vincenzo Bellini (1801-1835) (cujo enredo é parodiado na comédia), desprezando as cantigas nacionais. José pretende casar sua filha, Josefina, com Marcelo, um fazendeiro rico, tocador de viola, o qual, a princípio, é mostrado como um rústico e ignorante, mas, no final, acaba surpreendendo os citadinos deslumbrados. O ator Germano de Oliveira, no papel do fazendeiro Marcelo, devia cantar se acompanhando na viola. Na cena IX, por exemplo, há a seguinte indicação:

JOSÉ ANTÔNIO - Atenção! (toca no piano a introdução do dueto da Norma; logo que deve principiar o canto diz José Antônio: Agora! Merenciana canta como no princípio. Ao dizer estas palavras, Marcelo, que disfarçadamente tomou a viola, principia a cantar em voz alta, acompanhando-se com a viola)

espanholas. Lolo (2002).

27 As informações sobre José Cândido da Silva foram colhidas em exemplares do Diário do Rio de Janeiro, publicados entre os anos de 1833 e 1854.

28 O ator português Germano de Oliveira chegou ao Brasil em janeiro de 1829. Tinha vocação fortemente dramática, chegando a rivalizar com João Caetano (PRADO 1972:187). A informação de que Germano interpretava o personagem de Marcelo na comédia O diletante foi publicada em 24/09/1853, no jornal O Globo, em São Luís, no estado do Maranhão, onde Germano apresentou comédias de Martins Penna durante a década de 1850, empresariando uma companhia no Teatro Nacional daquela cidade.

29 José de Alencar (apud MAGALHÃES JR. 1972:81) define o diletante como "um sujeito que vê a cantora, mas não ouve a música que ela canta; que grita bravo justamente quando a prima-dona desafina, e dá palmas quando todos estão atentos para ouvir uma bela nota”. 


\section{MARCELO}

Sou um triste boiadeiro.

Não tenho tempo de amar:

De dia pasto o meu gado,

De noite para rondar.

JOSÉ ANTÔNIO - Cale-se com trezentos milhões de diabos, sô papa-formigas! (vai para Marcelo, que continua a cantar).

(MARTINS PENNA 2007 [1844]:375, vol. I).

José Cândido, no papel do diletante, por seu turno, tocava trechos ao piano ${ }^{30}$, além de cantar e assoviar, em tom de paródia, árias e duetos da Norma:

JOSÉ ANTÔNIO - Que dizes, bárbara? A “Casta Diva” maçada? Esta sublime produção do sublimíssimo gênio?

JOSEFINA - Será sublimíssima, mas como há algum tempo para cá que eu a tenho ouvido todos os dias cantada, guinchada, miada, assobiada e estropiada por essas ruas e casas, já não a posso suportar. Todos cantam a "Casta Diva"- é epidimia!

JOSÉ ANTÔNIO - E o mais é que tens razão. Ouve-se daqui: (canta a "Casta Diva" com voz fanhosa) Ouve-se dali: (canta com voz muito fina) Mais adiante um moleque: (assobia-a) Estragam-na! Assassinam-na! Mas tu cantas bem.

JOSEFINA - Obrigada, mas não a cantarei mais!

JOSÉ ANTÔNIO - Está bom; mas há de cantar o dueto: "Mira, o Norma, a tuoi ginocchi..." (cantando)

JOSEFINA - E com quem? O papá faz a parte da Norma?

JOSÉ ANTÔNIO - Com tua mãe.

JOSEFINA - A mamã cantando!... Ela, que apenas canta a "Maria Caxuxa” quando está cosendo, e isso mesmo desentoadíssima! Ora, papai!

(MARTINS PENNA 2007 [1844]:350-352, vol. I).

O avesso cômico das árias de ópera, no trecho acima, é a menção à canção "Maria Caxuxa", que Josefina, esposa do diletante, desafina ao cantar. A cachucha era original-

$30 \mathrm{O}$ fato de o texto da comédia $O$ diletante solicitar aos atores que cantem e toquem instrumentos não deveria impressionar, pois atrizes como a portuguesa Ludovina Soares - primeira dama da Companhia dramática do Teatro de São Pedro -, cantavam e tocavam harpa (CARDOSO 2011:318), o mesmo ocorrendo na Europa. Como assinala Benevides (1992 [1883]:8), em 22/06/1818, no Teatro de São Carlos, em Lisboa, a cantora italiana Carolina Beri-Passerini cantou três árias, uma em português, outra em francês, outra em italiano, acompanhando-se com a guitarra (violão). D’Amico (1954:138, vol. II), por seu turno, observa que, desde o século XVI, sempre havia nas companhias dell'Arte alguém que sabia cantar e que, além disso, alguns argumentos eram escritos especificamente para atores músicos, como Gabrielli. Em Os instrumentos de Scapino, por exemplo, o artista tocava violino, viola, contrabaixo, guitarra, trombone, mandolim, teorba e alaúde. Outros comediantes, ainda, tornaram-se famosos por suas imitações de instrumentos musicais ou pelas canções onomatopaicas nas quais simulavam vozes de animais. 
mente uma dança popular espanhola, em compasso ternário simples ou binário composto. Tinha acompanhamento de castanholas e andamento acelerando do moderado ao vivo, sendo interpolada com outras danças em apresentações teatrais, sempre como dança lasciva a tentar os homens (CALVO 2012:384-403). Em Portugal, nas décadas iniciais do século XIX, a cachucha foi apropriada e a letra da canção passou a fazer menção a uma personagem popular, licenciosa, brejeira e farsesca, a "Maria Cachucha" (ou Capucha), que dorme acompanhada por um gato preto e bravo que a "arranha" no traseiro, ou por certo frade Bento (TEIXEIRA 1981) ${ }^{31}$.

Assim como, em O diletante, os personagens de José Antônio e Marcelo estão associados à ópera italiana e às modas rurais - enquanto que a personagem de Josefina remete à "Maria Caxuxa" -, na comédia Quem casa quer casa, por sua vez, também há uma tipologia contrastante de personagens reforçada pelas menções e números musicais do texto. A comédia foi estreada, como dissermos, em benefício de José Cândido, o qual deve ter interpretado o personagem do gago Sabino, que fala cantando em ritmo de muquirão, polca e miudinho para se fazer entendido pelos moradores da casa:

SABINO (falando ao mesmo tempo no tom do miudinho) - Se continuo a viver assim junto, faço uma morte. Ou o senhor, que é meu sogro, ou meu pai, deem-me dinheiro... dinheiro ou casa, ou leva tudo o diabo...

(MARTINS PENNA 2007 [1845]:109, vol. III).

Segundo os anúncios de periódicos da época, o termo "Miudinho" designava uma dança popular, "lasciva", sendo usado, ainda, como adjetivo associado a danças correlatas, como certo "fado tão gostoso, tão engraçado, tão miudinho, [que] glosa umas quadras a pedido de certa madame" (Diário do Rio de Janeiro, 05/12/1833). Ao contrário das danças miudinho, polca e muquirão - de caráter mais "popular" -, o personagem antípoda ao gago Sabino é um "erudito" tocador de rabeca (violino). Eduardo vive de favor na casa da sogra e passa os dias infernizando os moradores da casa, praticando, em vão, uma composição denominada "Tremolo de Bériot":

OLAIA - Deixar ele a rabeca? A mamãe bem sabe que é impossível.

FABIANA - Impossível? Muito bem!

OLAIA - Apenas levantou hoje da cama, enfiou as calças e pegou na rabeca - nem penteou os cabelos. Pôs uma folha de música diante de si, a que ele chamou seu Tremolo de Bériot e agora verás - zás, zás, zás! (fazendo o movimento com os braços). Com os olhos esbugalhados sobre a música, os cabelos arrepiados, o suor a correr em bagas ela testa e o braço num vaivém que causa vertigens!

(MARTINS PENNA, 2007 [1845]:67, vol. III).

31 A primeira referência sobre a cachucha ("caxuxa") que encontramos no Diário do Rio de Janeiro data de 31 de outubro de 1823, cerca de um ano após a Independência, quando foi anunciado um programa no Real Teatro de São João, em benefício da atriz e dançarina brasileira Estela Sezefreda - a mesma que protagonizou as farsas $O$ juiz de paz da roça e $A$ família e a festa da roça de Martins Penna. Para mais informações sobre a caxuxa, cf. ULHÔA; COSTA-LIMA NETO (2013). 
Segundo Arêas (1987), Quem casa quer casa é comédia que mais se aproxima da "ópera cômica brasileira” - que Martins Penna planejava criar, como já assinalado em seus folhetins. Acreditamos que não apenas a referida comédia se direciona para o modelo da opèra comique - ou seja, diálogos falados entremeados de canções -, como também exemplifica outros conhecimentos musicais por parte de Martins Penna. O monólogo do violinista Eduardo, a seguir, serve de exemplo para o queremos assinalar:

EDUARDO - (...) O homem de talento não deve ser imitador; a imitação mata a originalidade e nessa é que está a transcendência e especialidade do indivíduo. Bériot, Paganini, Bassini e Charlatanini muito inventaram, foram homens especiais e únicos na sua individualidade. Eu também quis inventar, quis ser único, quis ser apontado a dedo... Uns tocam com o arco... (N.B.: Deve fazer os movimentos, segundo os vai mencionando) Isto veio dos primeiros inventores; outros tocam com as costas do arco... ou com uma varinha... Este imita o canto dos passarinhos... zurra como burro... e repinica cordas.... Aquele toca abaixo do cavalete, toca em cima no braço... e saca-lhe sons tão tristes e lamentosos capazes de fazer chorar um bacalhau. Estoutro arrebenta três cordas e toca só com uma, e creio mesmo que será capaz de arrebentar as quatro e tocar em seco... Inimitável instrumentinho, por quantas modificações e glórias não tens passado? Tudo se tem feito de ti, tudo. Tudo? (levantando-se, entusiasmado). Tudo não; a arte não tem limites para o homem de talento criador... Ou eu havia de inventar um meio novo, novíssimo de tocar rabeca ou havia de morrer. [...] Depois de muito pensar e cismar, lembrei-me de tocar nas costas da rabeca... Tempo perdido, não se ouvia nada. Quase enlouqueci. Pus-me de novo a pensar... Pensei... cismei... parafusei... parafusei... pensei... pensei... Dias, semanas, meses... Mas enfim, ah, ideia luminosa penetrou este cansado cérebro e então reputei-me inventor original. Até agora estes aprendizes de rabeca desde Saëns até Paganini, coitados, têm inventado somente modificações do modo primitivo: arco para aqui ou para ali... Eu, não, inventei um modo novo, estupendo e desusado: eles tocam a rabeca com o arco, e eu toco a rabeca no arco - eis minha descoberta! (Toma o arco na mão esquerda, pondo-o na posição da rabeca; pega nesta com a direita e a corre sobre o arco.) É esta a invenção que há-de cobrir-me de glória e nomeada e levar meu nome à imortalidade... Ditoso Eduardo! Grande homem! Insigne artista!

(MARTINS PENNA, 2007 [1845]:98-99, vol. III).

O trecho citado menciona, ironicamente, técnicas "modernas" do violino ("tocar com as costas do arco", "abaixo do cavalete", "repinicando as cordas", imitando "o canto dos passarinhos"). Como assinalado por Grout \& Palisca (1994 [1988]), estas técnicas foram inauguradas ou sistematizadas pelo violinista virtuose italiano Niccolò Paganini (17821840), mencionado diversas vezes no decorrer da comédia Quem casa quer casa, junto a outros compositores e intérpretes europeus:

EDUARDO - Ah, desde a noite em que pela primeira vez ouvi no Teatro de São Pedro de Alcântara os seus harmoniosos, fantásticos, salpicados e repinicados sons, senti-me outro. Conheci que tinha vindo ao mundo para artista rabequista. Comprei uma rabeca - esta que aqui vês. Disse-me o belchior que a vendeu que foi de Paganini. Estudei, estu- 
dei... Estudo, estudo...

PAULINA - É nos o pagamos.

EDUARDO - Oh, mas tenho feito progressos estupendíssimos! Já toco o Tremolo de Bériot... Estou agora compondo um tremulório e tenho em vista compor um tremendíssimo tremolo.

(MARTINS PENNA, 2007 [1845]:95, vol. III).

A composição acima referida de maneira irônica trata-se do "Trêmolo, capricho sobre um tema de Beethoven, para violino Op. 30", de autoria do compositor belga Charles-Auguste de Bériot (1802-1870). Assim como as composições de Paganini o "Trêmolo" de Bériot é uma peça de execução extremamente difícil, que solicita ao intérprete a utilização de diversas técnicas, além do recurso exaustivo do trêmolo. Este é um tipo de articulação no qual o violinista tem que alternar rapidamente o arco, produzindo um som rascante, totalmente adequado, aliás, ao personagem irritante de Eduardo. É importante notar, com Prado (1972:75), que uma das funções do "famoso trêmolo da orquestra" era sublinhar as "cenas de emoção" dos melodramas. "A música abria o espetáculo, marcava as entradas e saídas principais (o vilão, nos primeiros tempos, entrava sempre furtivamente, na ponta dos pés, cobrindo o rosto com o braço levantado)". Assim, por meio do trêmolo, Martins Penna tomava emprestada a fórmula do melodrama para parodiar este gênero, num misto de reverência e ridículo. ${ }^{32}$

"Le Trêmolo" foi tocado na Corte por violinistas como o português Francisco de Sá Noronha ${ }^{33}$ e pelo italiano Agostinho Robbio, o qual viajava se apresentando pelo Brasil e pelo mundo dizendo-se discípulo de Niccolò Paganini - sem nunca o ter sido (CYMBRON 2012:310). Em 25 de agosto de 1845, apenas três meses antes da estreia de Quem casa quer casa, Agostinho Robbio apresentou um benefício no Teatro de São Pedro, ao qual Martins Penna deve ter estado presente ${ }^{34}$, decidindo parodiá-lo na comédia. Assim, enquanto o personagem de Eduardo imitava Robbio e seu famoso "Trêmolo", o barítono José Cândido da Silva, no papel do gago Sabino, por seu turno, criava letras de canção em ritmo de muquirão, miudinho e polca - como se o texto da comédia fosse um libreto de ópera bufa ou cômica.

32 Como assinala Hutcheon (1985:28), a maioria dos teóricos da paródia associa a origem do termo ao substantivo grego parodia (contracanto), apesar de a paródia nem sempre ir "contra" um texto, pois frequentemente este é respeitado como modelo. Segundo a autora, o prefixo para tem dois significados: a) "contra" ou "oposição" e; b) "ao longo de" ou "próximo de" - o segundo significado sugerindo acordo ou intimidade, ao invés de contraste. A paródia tem, assim, natureza ambivalente, pois é tanto reverência como transgressão, admiração e ridículo mordaz.

33 Ver a "Notícia Biográfica sobre o rabequista português Francisco de Sá Noronha", publicada no jornal A Aurora, 22/06/1851.

34 Há registros de passagens de Robbio por vários países: Açores (1843), Brasil (1845), Argentina (1849), Portugal (1850-1851), Argélia (1853), Cuba (1854), EUA (1855), Austrália e Japão (1863) (CYMBRON 2012:310-311). 


\section{4-1863 - Companhia dramática (mista) de João Caetano}

Se a quantidade de comédias novas de Martins Penna, apresentadas no Teatro de São Pedro, já vinha diminuindo desde as censuras sofridas pelo autor em fins de 1845, após sua morte, em dezembro de 1848, nenhuma de suas comédias foi ali encenada. A abolição do tráfico, em setembro de 1850, contudo, provocou o afastamento da antiga diretoria, presidida pelo traficante ne greiro português José Bernardino de Sá. Foi assim que, em 1851, João Caetano retornou ao Teatro de S. Pedro, reunindo em uma só companhia atores brasileiros e portugueses, meses antes de um incêndio de origem aparentemente criminosa - talvez um ato de vingança da antiga diretoria - ter destruído completamente o teatro. Somente dois anos depois, em 1853, o Teatro de S. Pedro pode ser reinaugurado, voltando a abrigar, com sucesso, as comédias de Martins Penna, até o falecimento de João Caetano, em 1863. Após a morte do grande ator, ex-atores de sua companhia continuaram em atividade, apresentando as comédias de Martins Penna, enquanto os textos, publicados pela tipografia de Paula Brito, eram comercializados em profusão ${ }^{35}$.

Apresentando-se, desde 1844, nos teatros de São Januário, Santa Tereza, São Francisco e, a partir de 1853, no de S. Pedro, a companhia de João Caetano encenou as seguintes comédias de Martins Penna: O juiz de paz da roça (1844), Os irmãos das almas (1848, 1853), Os dois ou o inglês maquinista (1849, 1850, 1856), O Judas em sábado de aleluia (1849, 1857), O noviço $(1853,1854,1855,1856,1857,1858,1860)$ e A família e a festa da roça (1855). As comédias eram estreladas pelo ator-cantor-dançarino negro Martinho Correia Vasques, referido elogiosamente por Martins Penna no folhetim abaixo:

Outro ator do Teatro de S. Francisco, o Sr. Martinho, tem ultimamente mostrado as mesmas disposições que o Sr. José Cândido. [...] Na ária da polca, o Sr. Martinho teve as honras do da capo ${ }^{36}$. É esta a vigésima ou trigésima vez que a canta em cena; essa única circunstância é um grande elogio. [...] Na noite do espetáculo em benefício dos dois meninos, cantou ele [o Sr. Martinho] a ária do Mascate Italiano de um modo que revela grande talento e naturalidade para os papéis bufos. Sua voz é agradável e sonora, e melhor do que geralmente se exige para os papéis bufos; seus gestos (a par de alguma exageração), são naturalmente engraçados, e a mobilidade de sua fisionomia excita sempre a hilaridade do público; pouco falta, pois, ao Sr. Martinho, para ser um bom cantor bufo, se quiser dar-se ao trabalho de estudar música e o italiano. Não o atemorize o estudo e nem recue diante da dificuldade; em primeiro lugar, tudo se vence com paciência e perseverança, e em segundo lugar, o estudo da música e da língua italiana não é cousa de meter medo a um artista que mostra

35 Entre os anos de 1842 a 1855, Paula Brito publicou oito comédias de Martins Penna, num total de quinze edições (RAMOS JR. 2010:241-243).

36 "Da capo" é uma expressão musical em italiano, significando que um determinado trecho musical deve ser repetido. No contexto do folhetim acima referido, Martins Penna assinalou que a performance de Martinho, cantando a "Ária da polca", teve tal sucesso de público que a mesma ária foi repetida integralmente pelo artista, como um bis. 
inteligência como o Sr. Martinho (Folhetins, 1965 [25/08/1847]:339-340 - nossos destaques).

O folhetim citado contém um dos maiores elogios feitos por Martins Penna a um artista brasileiro, superado somente por aqueles dirigidos pelo folhetinista ao ator e empresário João Caetano, de quem era amigo. Martinho foi o ator-cantor cômico mais prestigiado do Rio de Janeiro nas décadas de 1840 e, principalmente, 1850, quando a companhia de João Caetano voltou ao Teatro de São Pedro. É perfeitamente coerente supor que Martins Penna via em Martinho uma das futuras estrelas da "ópera cômica brasileira", que o primeiro planejava criar, paralelamente à fundação do Conservatório de Música.

O nome de Martinho Correia Vasques aparece nos periódicos cariocas a partir de 29 de setembro de 1842, quando o artista iniciou sua trajetória profissional nos palcos, atuando no Teatro de São Pedro. Em maio de 1843, Martinho entrou na companhia de João Caetano, na qual permaneceu até 1863. Após o falecimento do empresário e ator, Martinho parece ter se retirado gradativamente de cena, antes de se ver obrigado a voltar aos palcos, devido a razões econômicas (BASTOS 2007 [1898]:488). Em 1865, atuou n'O noviço, cantando, ao final da comédia, a "Ária do Mascate italiano"; em outubro de 1872, participou da mágica A Pera de Satanás, no Teatro São Luiz, com a companhia de Furtado Coelho e, em 1874, encerrou sua carreira se apresentando em Salvador (Bahia), novamente no papel do noviço Carlos, na comédia de Martins Penna. ${ }^{37}$

O repertório híbrido apresentado por Martinho nos teatros incluía o gestual musical afro-brasileiro presente no fado, no lundu e no miudinho, recebendo, ainda, a influência do vaudeville francês e das árias de ópera bufa italiana. Consistia este repertório, em primeiro lugar, de "árias cômicas encenadas", mistas de canto, teatro e dança. Estas cenas musicadas eram intituladas "Ária do mascate italiano" e "Ária da Polca" - ambas referidas elogiosamente por Martins Penna no folhetim antes citado. Outros títulos incluem a "Ária do Capitão mata-mouros", do "Miudinho", "Pritixe", "Os apuros de um beneficiado", da "Negrinha-Monstro", do "Romântico estragado", da "Polca das rosas", do "Boleiro apaixonado" e do "Acendedor de lampião a gás". Martinho atuava também em farsas, comédias com e sem música, além de dramas, melodramas e "tragédias-cômicas"38.

Devido à ausência de partituras, não é possível sabermos como eram as músicas apresentadas por Martinho, mas mesmo se tivéssemos registros em partitura da prática musical oitocentista, não seria possível sabermos exatamente como era sua performance.

37 As informações sobre Martinho Correia Vasques foram colhidas em exemplares do Diário do Rio de Janeiro, publicados entre os anos de 1842 a 1874.

38 Segundo os anúncios do Diário do Rio de Janeiro, as árias cômicas "da Polca" e do "Acendedor de lampião a gás" foram compostas, respectivamente, por José Joaquim Goyanno e Henrique Alves de Mesquita. A comédia Cosimo ou o príncipe caiador (1844), por sua vez, teve música do compositor e violinista português Francisco de Sá Noronha, enquanto que Gringalet (1851) foi musicada pelo violinista Demétrio Rivero. A comédia Fantasma Branco (1852), por fim, com texto de Joaquim Manuel de Macedo, teve música do maestro de coro Dionizio Vega (o qual, antes de ser maestro, fora ponto no Teatro de S. Pedro). Cf. Augusto (2014) para mais informações sobre H. A. de Mesquita. 
Neste sentido, mais útil do que uma partitura é o folhetim antes citado de Martins Penna, por revelar as características bufas de Martinho, como sua "voz agradável e sonora”, seus gestos "naturalmente engraçados" e sua fisionomia que "excita sempre a hilaridade do público". Como assinalado por um comentarista português do século XVIII:

O buffo faz com que sua audiência entenda tudo que ele canta [...]. Eles usam certos sons para exprimir raiva, dor, alegria, em suma, eles têm expressão, que é a verdadeira música do drama. Eles podem quase ser considerados como mímicos, apesar de os italianos não os verem como tal (LIMA apud BRITO 1989:112 - nosso grifo).

A empatia de Martinho servia como chamariz para as plateias, inclusive para os espetáculos realizados em benefício da alforria de escravos e de irmandades de negros, pardos e homens livres pobres ${ }^{39}$, nos quais ele simultaneamente atuava, dançava e cantava. Martinho encontrava, assim, similaridade com um cantor ou ludius romano, ator-dançarino que dançava seu papel ao som do aulo e do escabelo, espécie de tamanco percutido com os pés pelo músico (DUPONT 1988:21-22). Poderíamos referir, com o mesmo intuito, que seu repertório, constituído de "árias cômicas encenadas", era comparável ao dos atores dell'Arte. Estes representavam partes fixas (dois velhos e dois criados, dois casais de enamorados), em contraste com as partes móveis (o capitão, o mago, a soubrette, o deus ex machina, além de figurantes e objetos animados) - na copresença de tradição e modernidade (RABETTI 2014:16).

Estreada em 1845, pela companhia dramática portuguesa, a comédia em 3 atos $O$ noviço era apresentada como a parte principal do extenso programa teatral oitocentista. Como os anúncios de periódicos revelam, os intervalos entre os atos eram preenchidos com "números" que incluíam desde árias e duetos de ópera italiana, até curiosas misturas de teatro, música e dança, além de exibições de malabarismo, ilusionismo, mágica, exercícios ginásticos e com feras amestradas. Martinho Correia Vasques seguiu este costume, mas introduzindo seu próprio repertório de árias cômicas encenadas, das quais conseguimos localizar a letra a seguir:

"Ária do Capitão mata-mouros"

Eu já tive por bastão

O tronco de uma mangueira

Já tive por cabeleira

Um enchimento de colchão;

39 Segundo os anúncios do Diário do Rio de Janeiro, publicados na década de 1840, Martinho Correia Vasques participou de oito espetáculos em "benefício para uma liberdade", ou seja, utilizando a receita obtida com a venda de bilhetes para adquirir a alforria de um escravo. Além dos benefícios para a liberdade de escravos, Martinho participou de espetáculos em benefício das irmandades: Nossa Senhora da Lampadosa (4), Nossa Senhora das Dores da Freguesia do Sacramento (1), Nossa Senhora do Socorro (1), do Divino Espírito Santo da Freguesia de Santana (1), e Nossa Senhora da Soledade (1). 
Por ter firme o coração

E ser no amor afeito,

A uma dama de jeito,

Com paixão como não vi,

Dez anos eu trouxe aqui...

Como alfinete no peito.

Tudo quanto tenho exposto

Passará por caçoada,

Assim não direi mais nada

Para não vos dar desgosto:

Vou cumprir d'este meu posto

$\mathrm{O}$ que nele muito abunda,

Com figura tão jocunda

Não me posso demorar,

Pois vou patrulhas rondar

Da Armação ao Quebrabunda.

Revista O trovador (1876:56-57).

Il Capitano era um personagem da Comedia dell'Arte italiana, metido a conquistador de mulheres e grande contador de vantagens e mentiras, ${ }^{40}$ que falava com sotaque espanhol, aludindo criticamente aos soldados espanhóis que invadiram a Itália durante algum tempo (CARVALHO 1994:59). Personagens como os Enamorados, Arlequim e Scaramouche (um dos nomes do Capitã ${ }^{41}$ ) influenciaram a caracterização das antigas óperas cômicas até a época de Wolfgang Amadeus Mozart (SADIE 1994:209). A figura do Capitão aparece na ópera bufa napolitana a partir do início do século XVII, sempre tendo o respectivo cantor o registro vocal de baixo. Este é o início de uma tradição continuada por Gaetano Latilla, Baldassare Galuppi, Carlo Goldoni, Giovanni Paisiello, Domenico Cimarosa e W. A. Mozart ${ }^{42}$. A tradição será continuada nas tonadillas e zarzuelas espanholas dos séculos XVII e XVIII (ALIER 2011), chegando ao Brasil oitocentista e às árias cômicas encenadas pelo baixo Martinho Correia Vasques. A letra da "Ária do Capitão mata-mouros" preservou as características milenares do famoso personagem-tipo fanfarrão, enquanto, ao mesmo tempo, estas características eram atualizadas e reelaboradas criativamente por Martinho.

40 Antecedentes remotos da máscara do Capitão podem ser encontrados nos fanfarrões da comédia grega, no Miles Gloriosus de Plauto ou, ainda, na figura do "bravo" das representações medievais (D’AMICO 1954:111, vol. II). É interessante notar que no entremez português há o personagem do Chibante, sargento do exército e conquistador apaixonado, brigão e, ao mesmo tempo, covarde. (PAIVA 2010:56-57).

41 O personagem do Capitão na Commedia dell'Arte recebeu vários nomes e denominações: Spaventa de Vallinferna, Rodomonte, Matamoros, Coccodrilo, Bombardone, Scaribombardone, Spezzaferro, Spaccamonte, Fracassa, Bellavita, Zerbino e, ainda, Scaramouche (CARVALHO 1994: 67).

42 Ver Weiss ("Opera buffa". Grove Music online). 
Concluindo, as comédias $O$ juiz de paz da roça e A família e festa da roça receberam a influência musical do entremez português, em sua mistura de lundu afro-brasileiro e tirana ibérica. Foram estreadas pela companhia dramática de João Caetano, respectivamente, em 1838 e 1840, em benefício de atrizes-dançarinas brasileiras (Estela Sezefreda) e portuguesas (Maria Cândida da Conceição). Os números musicais foram executados nos finais das duas comédias, por um "coro" de atores, músicos e dançarinos, e estavam associados a situações, como bailes de casamento e cortejos realizados no espaço cênico da "roça”. As comédias O diletante e Quem casa quer casa, por sua vez, estrearam em 1844 e 1845, em benefício de artistas da companhia dramática portuguesa (Germano de Oliveira e José Cândido da Silva). Receberam forte influência musical da ópera italiana e, em menor grau, da música de concerto romântica europeia, sendo os números executados por solistas, duos e trios, no início e/ou no meio das comédias. Os números e menções musicais estavam relacionados principalmente aos personagens-tipo contrastantes, e aos espaços cênicos situados não mais na "roça", mas na cidade do Rio de Janeiro (com suas casas e ruas e o próprio Teatro de São Pedro).

Em O noviço, por fim, na qual não constam números de música e dança, aparece uma terceira configuração performativa. De 1853 a 1874, Martinho introduziu suas "árias cômicas" nos entreatos e/ou no final da mesma comédia onde ele representava o papel do noviço Carlos - uma espécie de malandro do século XIX, o qual, para escapar do Mosteiro de São Bento, traveste-se de mulher, engana os frades, a polícia e o abade. Assim, o ator-cantor-dançarino negro aproximava personagens-tipo do passado e do presente, em mais um exemplo da parceria duradoura entre Martins Penna e os atores e atrizes que representaram suas comédias.

\section{Bibliografia}

ALIER, Roger. La Zarzuela: la história, los compositores, los intérpretes y los hitos del género lírico español. Barcelona: Ediciones Robinbook, 2011.

ALVARENGA, Oneyda.. Música Popular Brasileira. São Paulo: Duas Cidades, 1982

ANDRADE, Mário de. Dicionário Musical Brasileiro. Belo Horizonte: Editora Itatiaia, 1989.

AREAAS, Vilma. Na Tapera de Santa Cruz: uma leitura de Martins Pena. São Paulo: Martins Fontes, 1987.

"Introdução". Martins Pena - Comédias. São Paulo: Editora Martins Fontes, 2007.

AUGUSTO, Antônio José. A Questão Cavalier: música e sociedade no Império e na República (1846-1914). Tese de doutorado. Rio de Janeiro. UFRJ, 308 p., 2008, Instituto de Filosofia e Ciências Sociais, 2008.

. Henrique Alves de Mesquita: da pérola mais luminosa à poeira do esquecimento. Rio de Janeiro: Folha Seca, 2014.

BASTOS, Antônio Sousa. Carteira do Artista: apontamentos para a história do teatro português e brasileiro. Acompanhado de notícias sobre os principais artistas, escritores dramáticos e compositores estrangeiros. Portugal, Lisboa: Arquimedes Livros, 2007 
[1ª. Edição 1898].

. Dicionário do Teatro Português. Portugal: Coimbra: Minerva, 1994 [1908].

BENEVIDES, Francisco da Fonseca. O Real Theatro de S. Carlos: desde sua fundação em 1793 até a atualidade. Lisboa: Inst. da Biblioteca Nacional e do Livro, 1992 [1883]. 2 vol.

BRITO, Manuel Carlos de. Opera in Portugal in the Eighteenth Century. Cambridge: Cambridge University Press, 1989.

BUDASZ, Rogério. Teatro e Música na América Portuguesa - ópera e teatro musical no brasil (1700-1822): convenções, repertório, raça, gênero e poder. Curitiba: DeArtes, 2008.

CALVO, Laura Cuervo. El piano en Madrid (1800-1830): repertorio, técnica interpretativa e instrumentos. Unpublished PhD Diss. Departamento de Musicologia. Universidad Complutense De Madrid, 546 p., 2012.

CARDOSO, Lino de Almeida. O Som social. Música, poder e sociedade no Brasil (Rio de Janeiro, séculos XVIII e XIX). Rio de Janeiro, Edição do autor, 2011.

CARVALHO, Ângela Materno de. "A Commedia dell'Arte”. In BRANDÃO, Tânia (org.). O teatro através da história. Rio de Janeiro, Centro Cultural Banco do Brasil, 1994, vol. I, p. 49-67.

CARVALHO, José Murilo de. A Construção Nacional: 1830-1889. Coleção História do Brasil Nação: 1808-2010. Rio de Janeiro: Objetiva, 2012.

CHALHOUB, Sidney. A Força da Escravidão - Ilegalidade e Costume no Brasil oitocentista. São Paulo: Cia. das Letras, 2012.

CHIARADIA, Philomena. A Companhia do Teatro São José: a menina-dos-olhos de Paschoal Segreto. São Paulo: Editora HUCITEC, 2012.

CONRAD, Robert Edgar. Tumbeiros - O tráfico de escravos para o Brasil. São Paulo: Editora Brasiliense, 1985.

COSTA-LIMA NETO, Luiz. Música, teatro e sociedade nas comédias de Luiz Carlos Martins Penna (1833-1846): entre o lundu, a ária e a aleluia. Tese de doutorado. Centro de Letras e Artes. PPGM/PPGAC. UNIRIO, 2014.

CRANMER, David. "A música nos entremezes e farças da tradição luso-brasileira do período colonial." Plural pluriel - Revue des Cultures de Langue Portugaise, no 10, 2012.

CYMBRON, Luísa. Olhares sobre a música em Portugal no século XIX: ópera, virtuosismo e música doméstica. Portugal, Lisboa: Edições Colibri, Centro de Estudos de Sociologia e Estética Musical da Universidade Nova de Lisboa, 2012.

D’AMICO, Silvio. História do Teatro Universal. Buenos Aires: Editorial Losada, 1954. Quatro volumes.

DEBRET, Jean-Baptiste. Debret e o Brasil - Obra completa. LAGO, Pedro Corrêa do (org.). Rio de Janeiro: Capivara Edit. Ltda., 2009.

DUPONT, Florence. Le Théâtre Latin. Paris: Armand Colin Editeur, 1988.

FREIRE, Vanda Lima Bellard. "As mágicas e a circularidade de gêneros musicais no século XIX”. In LOPES; Antônio Herculano; ABREU; Martha; ULHÔA; Martha Tupinambá de; VELOSO; Mônica Pimenta. Música e História no Longo Século XIX. Fundação Casa de Rui Barbosa. Rio de Janeiro, 2011. 
GODÓI, Rodrigo Camargo de. "Entre comédias e contos: a formação do ficcionista Machado de Assis". Dissertação de mestrado. Campinas. Programa de Pós-graduação em Teoria e História Literária. UNICAMP, 2010.

Grove Dictionary of Music. Acesso em 04/05/2016.

GROUT, Donald J.; PALISCA, Claude V. História da Música Ocidental. Lisboa: Gradiva, 1994 [1988].

GUINSBURG, J.; FARIA, João Roberto; LIMA, Mariângela Alves de. Dicionário do Teatro Brasileiro. São Paulo: Perspectiva, 2009.

HUTCHEON, Linda. Uma teoria da paródia: ensinamentos das formas de arte do século XX. Lisboa-Portugal: Edições 70, 1985.

LOLO, Begõna. "La tonadilha escénica, esse género maldito". Revista de Musicologia. XXV, 2, 2002.

MAGALDI, Sábato. Panorama do Teatro Brasileiro. São Paulo: Global, 2004 [1996].

MAGALHÃES JÚNIOR, Raimundo. Martins Pena e sua época. LISA /INL, 1972.

MARQUES, Daniel. 'Precisa arte e engenho até...': um estudo sobre a composição do personagem-tipo através das burletas de Luiz Peixoto. Dissertação de Mestrado. Centro de Letras e Artes da UNIRIO, PPGAC, 1998.

MARTINS PENNA, Luiz Carlos. Folhetins, a Semana Lírica. Rio de Janeiro: Ministério da Educação e Cultura, INL, 1965. . Martins Penna - Comédias. São Paulo: Martins Fontes, 2007, III volumes. . O juiz de paz da roça. Setor de Manuscritos da BNRJ. Localizador I-6, 27, $1 \mathrm{n}^{\circ}$ $1-3,1837$.

MELO, Guilherme de. A Música no Brasil: desde os tempos coloniais até o primeiro decênio da República. Rio de Janeiro: Imprensa Nacional, 1947 [1908].

MENCARELLI, Fernando Antônio. Cena aberta: a absolvição de um bilontra e o teatro de revista de Arthur Azevedo. Editora da Unicamp, 1999.

MEYER, Marlise. Folhetim: uma história. São Paulo: Companhia das Letras, 1996.

MOTA, Marcus. A dramaturgia musical de Ésquilo: investigações sobre composição, realização e recepção de ficção audiovisual. Brasília: UNB, 2008.

NERY, Rui Vieira. Para uma história do fado. Portugal: Público, Comunicação Social, AS, 2004.

PAIVA, Rejane Ferreira de. “A Vingança da Cigana: o diálogo do repertório lírico com o imaginário do teatro de cordel". In: CRANMER, David (coord./ed.). Mozart, Marcos Portugal e o seu tempo / and their time. Portugal: Lisboa: Edições Colibri / Centro de Estudos de Sociologia e Estética Musical, 2010, p. 53-66.

PRADO, Décio de Almeida. João Caetano. São Paulo: Perspectiva, 1972. . A personagem de ficção. São Paulo: Perspectiva, 1976.

RABETTI, Maria de Lourdes. "Presença musical italiana na formação do teatro brasileiro”. ArtCultura, Uberlândia, v. 9, n. 15, 2007.

. "A commedia dellarte: mito, profissão e arte". ArtCultura, Uberlândia, v. 16, n. 29, 2014.

RAMOS JR., José de Paula; DEAECTO, Marisa Midori; FILHO, Plínio Marcos (orgs.). Paula Brito: editor, poeta e artífice das letras. São Paulo: Editora da Universidade de 
São Paulo; Com Arte, 2010.

REIS, João José; GOMES, Flávio dos Santos; CARVALHO, Marcus J. M. de. O alufá Rufino: tráfico, escravidão e liberdade no Atlântico negro (c. 1822- c. 1853). São Paulo: Cia. das Letras, 2010.

Revista O trovador. Rio de Janeiro, 1876.

Revista Dyonisos. Órgão do Serviço Nacional de Teatro do Ministério de Educação e Cultura, Ano X, fev. 1966, no. 13.

SOBRINHO, Barbosa Lima. Os precursores do conto no Brasil. Rio de Janeiro: Ediora Civilização Brasileira, 1960.

RONDINELLI, Bruna Grasiela da Silva. Martins Pena, o comediógrafo do Teatro de São Pedro de Alcântara: uma leitura de O Judas em sábado de aleluia, Os irmãos das almas e O noviço. Dissertação de mestrado. UNICAMP, 2012.

SANTOS, João Caetano dos. Lições Dramáticas. Rio de Janeiro: Tipografia J. Villeuneuve, 1862.

SOUSA, Galante de. O teatro no Brasil. São Paulo: Ediouro, 1968.

SOUZA, Silvia Cristina Martins de. As noites do Ginásio: teatro e tensões culturais na Corte (1832-1868). Campinas: CECULT, 2002.

"O teatro de São Januário e o "corpo caixeral": teatro, cidadania e cons-

trução de identidade no Rio de Janeiro oitocentista". Associação Nacional de História -

ANPUH. XXIV Simpósio Nacional de História. 2007, p. 1-9.

TABORDA, Márcia. Violão e Identidade Nacional. Rio de Janeiro: Civilização Brasileira, 2011.

TEIXEIRA, Heitor Gomes. “Maria Cachucha ou Maria Capucha?” Revista Lusitana, n. 1. Instituto Nacional de Investigação Científica, 1981.

ULHÔA, Martha Tupinambá de; COSTA-LIMA NETO, Luiz. "Memory, History and Cultural Encounters in the Atlantic: the case of lundu". The World of Music (new series). Alemanha: Berlim: VWB - Verlag für Wissenchaft und Bildung, vol. II, 2013.

VEGA, Carlos. Estudios para los orígenes del tango argentino. $1^{\text {a }}$ edição. Buenos Aires: Editorial de la Universidad Católica Argentina /Educa, 2007.

VEIGA, Luiz Francisco da.. "Biografia de Luiz Carlos Martins Penna: o criador da comédia nacional". Revista Trimensal do IHGB. Rio de Janeiro: Garnier, Tomo XL, 1877.

WEISS, Piero. "Opera buffa". Grove Dictionary of Musicians. 